\title{
Protestantism and economic ethics: An example for the interaction of faith and fabric?
}

\author{
Huber, Wolfgang \\ Stellenbosch University \\ w-k.huber@t-online.de
}

\begin{abstract}
This text addresses a specific religious and ethical tradition, namely the protestant version of Christianity, and a specific field of what is currently referred to as 'applied ethics,' specifically economic ethics, in order to find out in which way this tradition and this field of applied ethics are interwoven and it does so in a situation in which both parts of this pair seem to be in trouble.
\end{abstract}

Key words

Economic ethics; Reformation; spirit of capitalism; contributively justice; market

\section{Economic ethics}

As far as economic ethics is concerned the triumphal march of a capitalistic market economy after the breakdown of state capitalism in the former communist regimes since the late 1980s remains in sharp contrast to the lack of inner legitimacy of this economic system. This is demonstrated by the fact that across the globe there seems to be a resurgence of the call for 'socialism' which is vaguely understood as an alternative economic order. Among the various reasons for the loss of inner legitimacy the following are in my view of significant importance: The one-sided emphasis on shareholder value that already culminated in the 1990s; the growing independence of the investment section of the financial markets that, during the 2008/2009 crisis, demonstrated their capacity regionally as well as globally, to endanger economic stability; and finally, the experience that vulnerable groups do not profit but feel excluded from the benefits of economic growth. In addition, the most dramatic challenges of our time - 
global climate change and the global refugee crisis - are without a doubt, at least in part, caused by economic developments.

The lack of legitimacy of the globally dominating variants of the capitalist market economy goes hand in hand with a lack of ethical clarity and moral consensus. In the process of globalization, the plurality of religious, cultural and ethical options has become indisputably obvious. Whether ethical worldviews would eventually achieve overarching moral consensus remains completely unclear. Some, neglected by others, debate the issue of whether or not religious beliefs still have a contribution to make. On the one hand, there is the worldwide growth of religious communities and the emergence of new kinds of religious groups, especially of indigenous, Pentecostal, charismatic and evangelical variants of Christianity. On the other hand, there is widespread denial of any relevance of religion for the 'life questions' of our time. The negligence - even denial - of the contribution religions could make, is strengthened by the continuing assumption that at least Europe and - astonishingly enough - North-America (jointly called 'the West') went through a process of secularization that can by no means be reversed. Let me illustrate this with reference to an example regarding the 'West' and the role of Christianity.

The American historian Brad S. Gregory, in his book The Unintended Reformation. How a Religious Revolution Secularized Society (2012) is one of many authors who presents the 'Middle Ages' as a time in which the religious fabric of society was consistent and homogeneous, and in which religion was clearly predominant as the guarantor of social cohesion. Authors like him often add that the Reformation, in contrast, brought with it a fragmentation of the fabric of society as became manifest in the confessional wars of early modernity. That finally made it necessary to construct the peace of nations on the basis of the adage 'etsi deus non daretur - as if there were no God,' to quote Hugo Grotius, a preeminent legal scholar of the $17^{\text {th }}$ century. Very generally reviewed, this turn is linked to the idea of an inevitable secularization of society, which means that at least since the enlightenment religion no longer plays any crucial role in weaving the social fabric.

This construction is problematic in all its three steps, namely the homogeneous Middle Ages, the dividing Reformation and the secularizing 
modernity. The perceived homogeneity of the Middle Ages has more to do with a Romantic construction than with the realities of those centuries, as they were already characterized by remarkable regional differences which led to manifold 'Micro-Christendom's' (Brown 2013: 355-380). They include movements of renewal and reform without which the Reformation of the $16^{\text {th }}$ century is not understandable at all. This process itself included not only fragmentation, but also a lively interaction of the different forms seeking to understand the Christian faith, including the Catholic reform that already began during the $16^{\text {th }}$ century (Kaufmann 2017). Not only this narrative of fragmentation, but also the narrative of secularization, has become highly debated, so that nowadays only a minority of the sociologists of religion favours them. For an alternative view, Hans Joas turns our attention to the plurality of options with regard to worldview and belief, combined with an ongoing interplay between sacralisation and desacralisation (Joas 2014). That the thesis of secularization is insufficient becomes even more evident when the issue is approached not only with the 'West' in mind, but also from a global perspective. From this perspective, religion, for better or for worse, is among those forces that contribute to the strengthening or the dissolution of the social fabric (Martin 2011).

Therefore, the question of the interplay between concrete formations of Christian ethics and applied ethics is not an outdated question. However, the unpacking and answering of this question has to bear historical developments and models in mind. Economic ethics in this regard provides a good example. Whenever it comes to the task of explaining the genesis of the modern capitalistic form of economy, its relation to a specific form of Christian belief and behaviour is on the agenda: The interaction of 'Protestant ethic and the spirit of capitalism' comes into play.

\section{The Weber Thesis}

The problem mentioned above, is associated with a name: we are directly reminded of Max Weber, one of the key figures of the emerging sociology, including the sociology of religion, at the turn of the $19^{\text {th }}$ to the $20^{\text {th }}$ century. His contribution to the topic is well-known right up to today, and has even been recognized at the German carnival in its stronghold in Cologne. One of the leading bands of this carnival put together a song some years ago, that 
begins with the following lines": "Max Weber once said, that only labour is important,/that God gives grace to those, who don't forget their duties./ Idleness and carnival are a waste of time./The one who earns a lot on earth, gets the best seat near to God." And the refrain starts with the words: "I am so happy that I'm not a Protestant,/they have nothing in mind but to work ..." (Radkau 2014: 239) So, in the carnival version we already find reference to the two elements of work ethic and of capital accumulation as characteristic of protestant economic ethics. In addition, Max Weber is held responsible for us knowing about it, not only by the carnival clowns of Cologne, but also by many intellectuals, economists, and politicians around the globe.

Let me illustrate that by means of a very different example. A decade ago, I visited the Chinese Office for Religious Affairs, eager to learn more about the official concept of the Chinese political approach to religion. Very rapidly, I was given the answer that the ideal combination of basic elements understood to be necessary for the fabric of the gigantic Chinese empire were Marxism, Capitalism, Protestantism and Confucianism. Marxism was named as justification of a one-party-system, Capitalism as engine for economic growth, Protestantism as the legitimation of capital accumulation and commitment, Confucianism as basis for obedience and a sense of duty and order. The South-Korean-American President of the World Bank, Jim Yong Kim, also mentioned the specific connection between Protestantism and Confucianism in an interview in 2014, in which he emphasized the so-called Weber thesis. He added that not only Protestantism, but also Confucianism could initiate economic dynamics, as the example of South Korea demonstrates (Frankfurter Allgemeine Zeitung, May 17, 2014). It appears that in intellectual circles in East Asia Protestantism is more often identified with the name of Max Weber than with the names of Martin Luther or John Calvin.

1 Max Weber hat gesagt, dass nur die Arbeit wichtig ist, dass der Herrgott den begnadigt, der die Pflichten nicht vergisst. Müssiggang und Karneval, das ist für die Katz, wer auf Erden viel verdient, hat bei Gott den besten Platz. Ich bin so froh, dass ich nicht evangelisch bin, die haben doch nichts anderes als arbeiten im Sinn. Als Katholik da kannste pfuschen, dat eine is jewiss, am Samstag gehste beichten und fott is der janze Driss. (http://www.gutefrage.net/frage/songtext-gesucht-comedy) 
This kind of typological understanding of the Protestant ethos is not restricted to the fields of economics or politics. In certain psychological research, 'protestant ethics' is seen as a 'personality variable' characterized by sexual guilt and moral conscience guilt, by authoritarianism, expectancy of internal control, and finally by a concrete, pragmatic approach to work which is negatively correlated with occupations that typically require emotional sensitivity, theoretical interests, and humanistic values (Mirels/ Garrett 1971). As a result, we can call the so-called Weber Thesis an ideal type of protestant ethic, bearing in mind, that ideal types in Weber's sense are not at all ideal. Although the authors reporting on this psychological research acknowledged that 'the validity of Weber's thesis concerning the causal relationship between Protestantism and Capitalism has been energetically debated' it did not withhold them from stating that 'the impact of the ascetic orientation (i.e. of Protestantism) on contemporary Western social institutions has been widely attested.' (Mirels/Garrett 1971, 40)

Regardless of the fact that the Weber Thesis has been criticized as to its historic validity for a long time, it was rejuvenated after World War II in order to explain the strength of the US-American model of managing their economy successfully. The unity between a committed Christian lifestyle and success in business was seen as a marker of the uniqueness of the American way as such. Weber's idea of worldly asceticism was transformed into one of high esteem for benefactors of different kinds, for philanthropic foundations, for cultural sponsorship, etc. Some years ago, Niall Ferguson even used this concept to explain the success of the US-economy compared to a perceived decline in the middle and north-western European economies in the early years of the $21^{\text {th }}$ century. He interpreted this as a decline of Protestantism in Europe, signalled also by a degradation of work ethic for which he took working hours per year and working years per lifetime as criteria. Evidently, his conviction was that the longer working hours of American workers had nothing to do with weak labour unions; rather, it indicated the strength of Protestantism in the Weberian sense (Ferguson 2003). Ten years later Ferguson included the United States of America in his gloomy prediction as well, and did not hesitate to compare his analysis in 'The West and the Rest' to Oswald Spengler's 'The Decline of the West' ('Der Untergang des Abendlandes,' $1^{\text {st }}$ ed., vol.1, 1918). Whereas Spengler 
had discerned a cultural decline in the West, Fergusson argues in terms of economical characteristics. Among the success factors of the West - now including America - he emphasizes technological innovation, medical progress, and the likes, but also pertinently work ethic and consumerism as two central elements of economic growth. These are factors that he finds to be more and more neglected. He therefore expects that the West will sooner or later economically be overruled by East Asia, especially China (Ferguson 2011). Ferguson foresees a point in time when China will replace the US as the biggest national economy in terms of the BIP. Four years ago, Ferguson expected that to happen in exactly 2017 (Ferguson 2013). Other analysts have, however, expressed doubt that this is likely to happen in the near future. Different from his earlier interpretations Ferguson now relativizes his former high esteem of the 'God factor,' but as far as the role of the work ethic is concerned he still, at least implicitly, uses a Weberian concept.

Nowadays the Weber Thesis is even applied with a completely contrary intention. This inversion of the thesis has been induced by developments in contemporary finance dominated capitalism with destructive consequences for workers and debtors dependent on it. Kathryn Tanner devoted her Gifford Lectures of 2016 to the topic 'Christianity and the New Spirit of Capitalism.' Her title already indicated that she intends to challenge Weber with his own arguments. She proposes that the pervasive force of finance dominated capitalism "might be countered by Christian beliefs and practices with a comparable capacity to shape people. Thus, these lectures reverse the project of ... Max Weber ..., while employing much the same methods as he used. Weber showed how Christian beliefs and practices could form persons in line with what capitalism required of them." Tanner's "lectures will demonstrate the capacity of Christian beliefs and practices to help people resist the dictates of capitalism in its present, finance dominated configuration" (Tanner 2016b, cf. Tanner 2016a). 'Weber's method' indicates that Tanner also finds a causal relationship between religious conviction and the structuring of the economy. The 'formation of persons' is seen as the key to the transformation of the economy. Whereas according to the Weber Thesis the image of the puritan personality and her worldly asceticism furthered the spreading of the capitalist spirit, Tanner's concept counters the cultural forms of finance- 
dominated capitalism. For her, Christian beliefs and practices have the capacity to help people "to resist the dictates of capitalism in its present, finance dominated configuration." To scrutinize and appraise Tanner's argument will, however, only be possible when her lectures appear in print.

An approach comparable to Kathryn Tanner's project was presented in a campaign under the title 'Radicalizing Reformation' (Duchrow et al. 2015). The authors summarize their concept in 94 theses that start with: "At least two billion people are impoverished by the domination of money. That is the contemporary expression of Mammon and therefore the central challenge for faith" (Duchrow et al. 2015: 5, 24). The consequence is "to drop out on a daily basis personally and socially from the destructive domination of money and to live - confident in the liberating justice of God - in compassion and solidarity in just relationships with other humans and creatures" (Duchrow et al. 2015: 1,28). Rather than articulating maxims for action by those with economic responsibility, or global regulations with regard to a globalized economy, the right strategy is regarded as one in which individuals and groups withdraw from the present state of affairs. This kind of withdrawal from the ruling system requires a personal dedication. As historical examples show, from time to time this may be an important pioneering approach, but it cannot be generalized as a moral standard for economically responsible subjects or for the regulation of the economy by legal rules. Therefore it is highly questionable whether the challenges related to a globalized and finance-dominated economy can be met by the instrument of personal or group withdrawal. There are obvious limits to an inverse use of the Weber Thesis.

As far as the causal interpretation of this thesis is concerned, Weber himself was, at least in a part of his formulations, quite careful, even to the point of risking compromising clarity. For instance, he described the relation between ascetic Protestantism and capitalism as an "elective affinity" (Wahlverwandtschaft) - an expression that allows for a certain vagueness on who elected whom and in which way. However, it cannot be my task to describe and critically analyse Weber's famous essays, of which the first was published in 1904/05, with later additions and revisions (see the rich material in Weber 2014; 2016). Instead, I will concentrate on one aspect of its implicit theology. 
Weber takes up a lay-theological interpretation of the teaching of John Calvin, the central figure of the second-generation Reformers of the $16^{\text {th }}$ century. He does so because he is convinced that this lay theology highly influenced Puritan Christians in early modernity, especially in North-Western Europa and then in North-America. According to this interpretation, the election of the individual Christian for eternal salvation can immediately be recognized in her relationship to temporal, mundane realities. Already in the second part of his studies on Protestantism, in the essay on 'Protestant Sects and the Spirit of Capitalism,' Weber emphasized the question of the "salvation premium" ('Heilsprämie') as the central point of his research. In the later revision of his text, he formally regretted that his critics had not considered this point. Literally he said: "Not the ethical doctrine of a religion, but that form of ethical conduct upon which premiums are placed, matters" (Seligman 1998: XXXII). In the case of Calvinism the salvation premium, or bonus, in Weber's understanding has a specific form that is related to the doctrine of double predestination, to salvation or damnation. No-one can live in absolute uncertainty in view of this double predestination. Therefore, people need at least "symptoms" of their election. In addition, the positive results of worldly asceticism in terms of economic success are such "symptoms" that give the certainty of belonging to a 'salvation aristocracy.'

That is, of course, a very brief summary of Weber's concept of salvation bonuses. But more important than a detailed description and interpretation of his text, is that Weber was unsuccessful in presenting historical evidence for the assumption that his kind of lay theology indeed shaped the culture in puritan communities to such an extent that the influence of this ethic on the emerging capitalism is plausible. There are also insufficient reasons for the assumption that the doctrine of double predestination created a kind of uncertainty that had to be and was indeed balanced by the concept of a salvation bonus for worldly asceticism. At least, this bonus was not consistently acknowledged. There was no guarantee for successful bankers in the Netherlands that they would not be excluded from the Eucharist as sinners - an idea that had caused some amusement in catholic Italy (Reinhard 2005: 283). Also, there was insufficient support for the assumption that the puritan capitalists became acquisitive virtuosi, because simultaneously they were religious virtuosi who aspired to be members of a salvation aristocracy. The assumption regarding the combination of 
financial bonuses and salvation bonuses was not based on solid ground. Finally, recent research finds no plausibility in the idea that this kind of worldly asceticism can explain "the shift of the focus of mercantile activity and entrepreneurial innovation from the Mediterranean to the north-west of the European continent" in the post-Reformation era. The history of European wars, the emergence of the Ottoman Turks, or the marginalized social position of dissenters who sought recognition, are examples of alternative explanations (Walsham 2015: 241f.).

Ernst Troeltsch, a close colleague and friend of Max Weber already stated in Weber's own time that it was then commonly understood that the big economic and social transformations of the $16^{\text {th }}$ century had happened independently of the religious movements of the time. These movements reacted to the transformations more or less reluctantly, and adapted to the new situation at differing tempos. Interestingly enough, in this regard Troeltsch saw the Catholic Church as more flexible than the Lutheran church (Troeltsch 1992: II, 869f.).

What in any case cannot be denied is that over time the link between financial success and election certainty lost all plausibility. Weber had anticipated that to a certain extent. He assumed that established capitalism reduces the spirit to the form. Later capitalism no longer needs a cultural basis as it did during early capitalism. However, there is yet another reason: The double predestination theory lost its credibility even for Calvinists or Presbyterians. Around the world, wherever you meet them, you will not easily come across any who are passionate about this doctrine. This is even more so in the broader stream of Protestantism in its different variants. As problematic as the historic argument is, the general assumption that the spirit which Protestantism contributed to the development of capitalism was the spirit of the 'salvation bonus.' That takes us a step further in our theological analysis.

\section{The concept of vocation}

There are good reasons for the assumption that the 'Protestant work ethic' rather than acquisitive capitalism underpins Reformation theology, because the Reformation developed her own clear concept on the value of human labour. This concept was very closely linked to a central theological interpretation of the standing of the human person before God. The concept 
of justification by God's grace alone, already formulated by St. Paul in the New Testament and rediscovered by Martin Luther, had answered the question of the status of people before God. This conception is completely incompatible with the idea of a 'salvation bonus.'

A central question within this concept of valuing human labour refers to the place of human action with regard to grace. The Reformers argue consistently that the quality of human deeds cannot be seen as a precondition for access to divine grace. This is because, measured against the criterion of God's will, no person will overcome her sinfulness by her own deeds; on the contrary, such an assumption will lead her even deeper into sinful self-centeredness. Worldly activities are not means of making God gracious towards humans; rather, they follow the gift of divine grace. Understanding Christian freedom as the liberation from self-centred, anxious worry about one's own salvation opens the way to a relational concept of the human person: One is related to God in faith, to one's neighbour as to oneself in love. The human person is constituted by faith; her deeds are measured by love.

To illustrate this understanding of the interaction between faith and deeds Luther uses the image of the tree and its fruits. It is not the fruit that makes a tree good. Instead, the good tree makes good fruits possible. The fruits follow the tree as the good works (Luther does not hesitate to use the term) follow faith. In this sense and in this sequence, together they constitute the whole of Christian life as a life in freedom.

In Luther's understanding, all worldly activity follows a divine calling and is in this sense a vocation. For this concept Luther prefers the word Beruf over against Ruf or Berufung; Beruf in his understanding can be translated by 'vocation' or 'calling' as well as by 'profession'. This use of the word has predecessors in the Middle Ages and is already reflected in Luther's translation of the New Testament of 1522. He develops this understanding further in the course of criticizing monastic vows (1522), and develops it in his sermons from 1522 onwards (Stegmann 2014: 360-390). He finds the idea of a special kind of status in Christianity that is distinguished from all other statuses by an inner vocation, unacceptable, because the divine justification addresses every person similarly - as a child of God, gifted with God's justifying grace. From there the equal status of every person in 
relation to God and to the world emerges. Every person therefore has an internal as well as an external vocation.

The inner vocation calls for unity of faith in God and of love to the neighbour as to oneself; the outer vocation expresses itself in a concrete mandate to a worldly activity in one of the major fields - in the language of the time - that is polity, economy (including family), and church. There is no longer any hierarchy regarding these fields. Whether a person works in politics, in the economy and family, or in the church does not matter. His or her profession has equal dignity to others and has to be respected in its usefulness for other individuals, for the greater community and for the common good.

It is interesting to realize how the foundation of human life on justification by grace alone is seen as constitutive of a fundamental equality of the different tasks of persons in their daily responsibilities. Whether they are simple support tasks in agriculture or family, the financial responsibility of a merchant or a banker, the political responsibility of a prince or the spiritual responsibility of a pastor in his congregation - in all these cases we see persons who are following their vocation. The concept includes paid work as well as voluntary work, the unpaid work of a mother as well as the paid work of a servant.

Work as vocation: that is the specific approach of the Reformation to economic ethics. This approach includes the responsibility of the entrepreneur as well as of the labourer; it includes the employee as well as the employer. On the basis of this understanding of 'Beruf', the core of what is called the Protestant work ethos may be defined as follows: Human labour is the use of one's talents and opportunities in order to fulfil useful and honest tasks and to do it productively not only to one's own benefit, but also to the benefit of others and the community. To make use of one's talents and opportunities, one needs appropriate education and formation. Therefore, it was not at all accidental that the Reformation turned out to be, at its centre, an educational movement.

Without a doubt, Luther's concept of work as vocation emphasizes the commandment to stay in the status into which a person is called. Compared to the rather static character of Luther's concept, Calvin seems to represent a more dynamic approach. 
His ethics can generally be understood as an 'Ethics of Gratitude.' Taking this approach, the Heidelberg Catechism, one of the central confessional documents of the early Reformed churches, summarized the intention of Calvin very well in the section on Christian life under the heading 'On gratitude.' Calvin himself emphasizes enjoying and using the divine gifts of creation as features of Christian life, and to use them. Because these gifts carry the danger of misuse - either by excess or by exaggerated frugality - using them prudently and measuredly is decisive. This approach follows from Christian freedom that, in Calvin's understanding, comprises three elements: Freedom from judgment by the divine law, the possibility of consciously loving God and fellow humans as yourself, and finally, independently dealing with the so-called 'adiaphora,' those questions for which no clear advice or commandment exists (Institutio III, 19). Issues related to ecclesial ceremonies, lifestyle or eating habits, but also questions of prudence in economic affairs belong to this 'middle ground,' i.e. they have to be dealt with consciously and decidedly, while taking into account the perspective of Christian responsibility.

In his understanding of work and profession, Calvin took the dynamics of economic development more seriously than Luther did (McGrath 1999). However, the idea, that success in profession and its monetary result are able to guarantee certain salvation, occurs neither in Calvin's nor in Luther's work. That is not astonishing, because for Calvin the bold theory of a double predestination - for salvation or damnation - means first, that God's transcendence has to be respected and his grace shall not be misunderstood as 'cheap grace.' (Bonhoeffer 1989: 29) In Calvin's view, the intention to gain salvation would even be annulled by the expectation of finding certainty on one's salvation from the successes of one's own working life. For a Christian the certainty of salvation lies for a Christian on the side of Christ and not on the side of the merit or the success of his/ her own deeds. At its heart Calvin's understanding of work as calling, is consistent with Luther's insight into the relevance of justification by grace alone for the understanding of human deeds.

Particularly notable is that the high premium placed on work has consequences for dealing with poverty. The Reformers criticize any spiritual elevation of poverty, and state in opposition to the mendicant orders the duty of everyone to take care of his/her own basic needs. Regarding 
the spiritual status there is no exception to the preference of work over living off alms. However, at the same time they distinguish "between the deserving and undeserving poor, between those able but unwilling to work and those incapacitated by illness or other circumstances beyond their control" (Walsham 2015: 242). They emphasize the responsibility of the political body to care for those who are unable to find their own livelihood. This is the starting point for a political concept of social welfare. Neither orders nor brotherhoods, but municipalities have to care for the poor and the needy within their walls. However, they are not obliged to give access to beggars coming in from the outside, mendicants included. Care for the poor became organized in the form of publicly administered funds ('Gemeiner Kasten'), prompted especially by the secularization of church treasuries. This consequence of the protestant work ethic regarding care for poor people followed remarkably quickly in many places.

\section{The distinction between interest and usury as touchstone}

Also of specific interest regarding the consequences of the high valuation of work for dealing with poverty, is how a 'preferential option for the poor' presents as a very important criterion for the reformers in dealing with a question of economic ethics that was of outstanding importance to them, namely the distinction between interest and usury in money lending (Nelson 1969).

This distinction was unheard of in the preceding period of theological thinking. In the preceding period the Biblical commandment that forbid taking interest - at least in dealing with your own people, your own community (Dt.23:19-20), was taken literally. The reformers had to deal with the transition from a home economy to a monetary economy. Of course, this transformation caused a lot of worry and distrust. Luther also had his misgivings regarding certain practices that emerged in the money economy. Usury became one of the core issues he dealt with during his whole career as a public writer. He argued against the tendency to raise extreme profits while professing love for fellow humans. As far as interest was concerned, he confronted creditors with the golden rule - to treat the other as you would be treated yourself - in asking whether the creditor would judge the imposed interest as fair, if he himself were in the position of the debtor. In remembering the Biblical commandment, he wanted to 
open a space for critical evaluation of a form of behaviour that was already seen as more or less normal in his times. Luther insisted on the question whether interest on loans or purchases indeed served both sides best. $\mathrm{He}$ dramatically challenged the asymmetric relationship in which creditors are enriched within a very short period to the extent that they easily "surpass kings and emperors", whereas others fall deeper and deeper into debt. However, he combined this sharp criticism with practical suggestions for a fair distribution of risk and a limitation of the interest rate.

With the distinction between interest and usury, the reformers accepted the functional use of interest that allowed for a temporal difference between buying and paying. In this respect, Calvin was more consistent than Luther was. He summarized his insights in a famous letter to Claude de Sachins in 1545 (Corpus Reformatorum 38, 1: 245-249) in which he argued for a hermeneutical procedure to understand the religious and ethical impulse of the Biblical commandment in its inner sense rather than in its literal proposal, and to use this inner sense as a criterion for dealing with the inherent logic of economic thinking (Nelson 1969: 75-82; Sauer 1997; Sauer 2003). Therefore, he interpreted the Biblical Commandment not as a general prohibition of interest as such. Instead, he drew attention to the objective of avoiding the detrimental effects of interest on a community. This danger has to do with the fact that the misfortune of the one is so easily turned into a benefit for the other in circumstances with an implicit tendency towards exploitation. As long as only the commandment not to take interest is stated repeatedly, the core issue is not even addressed. The question is actually about the rules that will prevent the exploitation of misfortunes or emergencies. The pragmatic usefulness of taking interest has to be balanced against respect for the other person who is, as every human being, created in the image of God, and whose destiny has therefore to be taken into account. This reflection brings Calvin, as other Reformers, to distinguish between interest and usury, in a manner that was not used in previous stages of this debate. The rate of interest and other conditions related to it, had to stay within the boundaries of equity; usury, in contrast, was understood as an exploitation of emergencies without respect for the integrity of the persons involved. To stay within given legal restrictions, to apply equity in conditions of economic exchange, and to respect the destiny of the poor are the main criteria under which the Reformers accepted interest as an instrument of economic exchange. 


\section{Conclusion}

What are possible consequences to be drawn from the brief sketch that has led our reflection from worldly asceticism to worldly service in the form of vocation, as the Reformers understood it, and to the preferential option for the poor, as the Reformers used it in their differentiation between interest and usury?

The possible consequences can be approached in either a descriptive or a constructive way.

As far as the descriptive way is concerned, I restrict myself only to one example, namely the preparatory steps that led to the model of social market economy developed in West Germany after World War II. Among those preparatory steps were remarkable contributions emerging from Catholic Social Teaching on the one hand, and from Social Protestantism on the other. Catholic Social Teaching emphasized the social character of the human person in arguing for social institutions that respect the person and promote solidarity and subsidiarity. Social Protestantism strongly underlined personal freedom as a central value for the understanding of human freedom. However, they found this personal freedom to be inseparable from responsibility not only for themselves, but also for other persons, and later even for nature and for future generations. From both perspectives the preference for a market economy was emphasized but on condition of a regulatory framework that would guarantee fair competition between the participants in the market, fair procedures for negotiating working conditions, and finally sufficient measures of social justice and social security (Jähnichen 2010). Therefore, it is evident that the milieus of Social Protestantism and Social Catholicism nurtured the emergence of the concept of a social market economy, as heterogeneous the conceptual strengths and weaknesses were that both sides contributed. As far as the protestant arguments are concerned, more rigorous research shows that their protagonists had neither a homogeneous understanding of their protestant religious identity, nor a convergent concept for the order of a market economy. On the one hand, an order by competition and on the other an order of competition was emphasized. A comparable ambiguity can be observed in respect of the relationship between the economic and the political order (Reuter 2010). 
This development of a social market economy commenced nearly seventy years ago. In the meantime, the fairness of competition was endangered by developments that could not be anticipated at the time. Working conditions became fragile and precarious due to a whole series of reasons, among which the development of a global labour market is of specific importance. The understanding of justice became challenged by the fact that it is no longer sufficient to look for justice in a seemingly closed society, as the conditions of a global society now have to be considered.

However, I argue for the position of not giving up on the potential of the concept of vocation, and specifically a broadened concept, in the sense of understanding human existence as active, creative, and productive life (Meireis 2008; 2010). Activity in this broad sense is a form of self-realization, but also a source of social recognition. The meaning of work changes but it does not disappear. At a time in which worldwide we observe employment becoming increasingly precarious and even growing unemployment, indifference towards the value of work is in conflict with the demands of justice. The protestant concept of the equal freedom of every person as the basis of individual responsibility as well as of social justice shows its relevance even under the conditions of our time.

That, of course, raises the question of what we mean by justice, understood in this case as the primary virtue of institutions (Rawls 1999: 3). Rawls understands justice as a system of equal freedoms. Given the fact that those equal freedoms are always realized in unequal ways, Rawls insists on a rule that clarifies which differences are acceptable and which are not. According to his difference, principle inequalities have to be seen from the perspective of a prerogative for the worst-off (Rawls 1999: 52-78).

What can a society do to improve the situation of the worst-off and to put in practice, in this sense, a 'preferential option for the poor?' Classical concepts answer that in such circumstances where commutative justice is not sufficient, distributive justice has to be implemented. The consequence is that social transfers from the rich to the poor have to be put into practice. Such distributive actions are necessary to alleviate poverty, but they are not sufficient to overcome it. They often end up in a kind of revolving door effect according to which those who pass through this door tend to do it repetitively. Therefore another kind of justice has to come into consideration for which the Catholic Bishops in the USA coined the term "contributively 
justice", i.e. a justice that enables people to contribute to the active life in society and therefore to use their gifts and talents, their opportunities and social conditions in order to live an active and productive life (United States Catholic Bishops 1986: 17; cf. Bedford-Strohm 1993: 88-106).

The elements of such a contributively or, as I would prefer to say, participatory justice are manifold (Evangelische Kirche in Deutschland 2006: 43-45). Among them, one element is of central importance, namely one the more recent discussion has termed 'enabling justice' (Dabrock 2012: 138-218). It makes use of the new insights of the 'capabilities approach' in the theory of justice as it was developed primarily by Martha Nussbaum and Amartya Sen (Nussbaum 2006; Sen 2009). It refers to all measures that promote the capabilities of persons to shape their own lives - through their health conditions or their self-confidence, their ability to play or their formation/education, through their belonging to communities or their ability to control their environment (Nussbaum 2006: 70-78). Education and formation play a central role in enabling justice.

A further element of contributively justice is evident in the social accessibility of meaningful work. The conditions for that accessibility change with every step in recent transformations of work, mostly by new technological means. The digitalisation of labour is a good example for that. There are advocates of a 'disruptive' digitalization of production irrespective of its effect on labour conditions or growing unemployment. Some of them propose an unconditional basic income that may free the state as well as economic enterprises from the responsibility to create new jobs for those who lose their previous ones. Advocates of an 'organic' digitalization ask for a kind of transformation that includes possibilities to stay employed for the people involved. The question is what drives this transition? From the perspective of participatory justice, there is a clear preference for an 'organic' transition where the decisive effort is to enable vulnerable people and not to lose them.

To achieve that goal it is necessary that the economy should be in the service of humans and not humans in the service of the economy. Amartya Sen, the Indian Winner of the 1998 Nobel Prize in Economic Sciences, spoke on Economy in the service of humans as a precondition for a development on a global scale that will promote freedom (Sen 1999). The coincidence between the insights of an Indian economist and an impulse leading back 
to Christian values as reflected in the Reformation tradition, in my view, turns out to be impressive.

To summarize: The critique of an exploitative use of misfortunes and poverty, as formulated by the Reformers, is based on the conviction that all humans are equal in dignity and should therefore have access to the opportunity to contribute productively to the common life of society and to the best of its members. Therefore, following through such a line of thought, contributively justice is a central criterion for the regulation of the economy. Practical knowledge is needed to institutionalize this contributively justice by means of education, formation, training and the organization of just participation in society.

This kind of evaluation needs a practice of reflexive equilibrium between the principles of a Christian (or other) ethics and the rules of economy. That would exactly fulfill what Shmuel Eisenstadt once called 'Wirtschaftsethik', which evaluates this specific institutional sphere on the premises of a specific religious or other ethical orientation (Eisenstadt, quoted by Seligman 1998: XXII). This kind of equilibrium could be a form of economic ethics suitable to our times.

\section{Bibliography}

Bedford-Strohm, Heinrich 1993. Vorrang für die Armen. Auf dem Weg zu einer theologischen Theorie der Gerechtigkeit. Gütersloh.

Brown, Peter 2013. The Rise of Western Christendom. Triumph and Diversity, A.D. $200-1000.10^{\text {th }}$ anniversary rev. ed. Chichester.

Dabrock, Peter 2012. Befähigungsgerechtigkeit. Ein Grundkonzept konkreter Ethik in fundamentaltheologischer Perspektive. Gütersloh.

Duchrow, Ulrich/Daniel Beros/Martin Hoffmann/Hans G Ulrich (Hg.) 2015. Die Reformation radikalisieren/Radicalizing Reformation, 5 Bände. Berlin.

Evangelische Kirche in Deutschland 2006. Gerechte Teilhabe. Befähigung $z u$ Eigenverantwortung und Solidarität. Eine Denkschrift des Rates der Evangelischen Kirche in Deutschland. Gütersloh. 
Ferguson, Niall. Why America Outpaces Europe (Clue: The God Factor), in The New York Times, June 8, 2003.

Ferguson, Niall 2011. Civilization. The West and the Rest. New York.

Gregory, Brad S 2012. The Unintended Reformation. How a Religious Revolution Secularized Society. Cambridge, MA and London, England.

Jähnichen, Traugott 2010. Das wirtschaftsethische Profil des sozialen Protestantismus. $\mathrm{Zu}$ den gesellschafts- und ordnungspolitischen Grundentscheidungen der Sozialen Marktwirtschaft, in Jahrbuch Sozialer Protestantismus 4, Gütersloh, 18-45.

Joas, Hans 2014. Faith as an Option. Possible Futures for Christianity. Stanford.

Kaufmann, Thomas 2017. Erlöste und Verdammte. Eine Geschichte der Reformation, 2 Aufl. München.

Martin, David 2011. The Future of Christianity. Reflections on Violence and Democracy, Religion and Secularization. Burlington.

Meireis, Torsten 2008. Tätigkeit und Erfüllung. Protestantische Ethik im Umbruch der Arbeitsgesellschaft. Tübingen.

Meireis, Torsten 2010. Was ist und worauf zielt sozialer Protestantismus, in Jahrbuch Sozialer Protestantismus 4, Gütersloh, 231-241.

Mirels, Herbert L./James B. Garrett. The Protestant Ethic as a Personality Variable, in Journal of Consulting and Clinical Psychology 36/1971, 40-44.

Nelson, Benjamin 1969. The Idea of Usury. From Tribal Brotherhood to Universal Otherhood, $2^{\text {nd }}$, enlarged ed. Chicago/London.

Nussbaum, Martha 2006. Frontiers of Justice. Disability, Nationality, Species Membership. Cambridge MA/London.

Radkau, Joachim. Leidenschaft im Eisschrank. Die lustvolle Qual Weberscher Wissenschaft oder: Die Aktualität Max Webers, in epdDokumentation 36/2014, 23-28.

Rawls, John 1999. A Theory of Justice, rev. ed. Cambridge MA. 
Reinhard, Wolfgang. Die Bejahung des gewöhnlichen Lebens, in Joas, Hans/Klaus Wiegandt (Hg.), Die kulturellen Werte Europas. Frankfurt a.M., 265-303.

Reuter, Hans-Richard 2010. Die Religion der Sozialen Marktwirtschaft. Zur ordoliberalen Weltanschaung bei Walter Eucken und Alexander Rüstow, in Jahrbuch Sozialer Protestantismus 4, Gütersloh. 46-76.

Sauer; James B 1997. Faithful Ethics According to John Calvin. The Teachability of the Heart. Lewiston, NY.

Sauer, James B. Christian Faith, Economy, and Economics: What Do Christian Ethics Contribute to Understanding Economy? in Faith and Economics 42, 2003, 17-25.

Seligman, Adam B 1998. Introduction, to: Richard H. Tawney: Religion and the Rise of Capitalism. New Brunswick/London. XI-XL.

Sen, Amartya 1999. Development as Freedom. Oxford.

Sica, Alan 2004. Max Weber and the New Century. New Brunswick/ London.

Stegmann, Andreas 2014. Luthers Auffassung vom christlichen Leben. Tübingen 2014.

Tanner, Kathryn. Inequality and Finance-Dominated Capitalism.

Recommendations for Further Reading, in Anglican Theological Review 98, 2016, 157-173 (Tanner 2016a).

Tanner, Kathryn 2016b. Christianity and the New Spirit of Capitalism.

[Online] Available: http://www.giffordlectures.org/lectures/christianity-and-newspirit-capitalism

Tawney, Richard H. The Acquisitive Society. New York 1920 (Gutenberg E-Book \#33741).

Tawney, Richard H 1998. Religion and the Rise of Capitalism. New Brunswick/London.

Troeltsch, Ernst 1992. The Social Teaching of the Christian Churches, vol. I, II. Louisville/KE. 
United States Catholic Bishops 1986. Economic Justice for All. Pastoral Letter on Catholic Social Teaching and the U.S. Economy, Washington DC.

Walsham, Alexandra 2015. Reformation Legacies, in Peter Marshall, The Oxford Illustrated History of the Reformation. Oxford. 227-268.

Weber, Max2014. Asketischer Protestantismus und Kapitalismus. Schriften und Reden 2004-2011 (Max Weber Gesamtausgabe I/9, ed. by Wolfgang Schluchter in cooperation with Ursula Bube). Tübingen.

Weber, Max 2016. Die protestantische Ethik und der Geist des Kapitalismus. Die protestantischen Sekten und der Geist des Kapitalismus. Schriften 1904-1920 (Max Weber Gesamtausgabe I/18, ed. by Wolfgang Schluchter in cooperation with Ursula Bube). Tübingen. 